\title{
Expeditious Quantification of Lignocellulolytic Enzymes from Indigenous Wood Rot and Litter Degrading Fungi from Tropical Dry Evergreen Forests of Tamil Nadu
}

\author{
Jenefar Sudarson, ${ }^{1}$ Shenbhagaraman Ramalingam, ${ }^{2}$ \\ Premalatha Kishorekumar, ${ }^{1}$ and Kaviyarasan Venkatesan ${ }^{1}$ \\ ${ }^{1}$ Mycology Laboratory, Centre for Advanced Studies in Botany, University of Madras, Chennai 600 025, India \\ ${ }^{2}$ Centre for Nanoscience and Technology, Anna University, Chennai 600 025, India \\ Correspondence should be addressed to Jenefar Sudarson; sjjene@gmail.com
}

Received 6 November 2013; Accepted 31 December 2013; Published 26 February 2014

Academic Editor: Triantafyllos Roukas

Copyright ( $) 2014$ Jenefar Sudarson et al. This is an open access article distributed under the Creative Commons Attribution License, which permits unrestricted use, distribution, and reproduction in any medium, provided the original work is properly cited.

\begin{abstract}
In this study thirty wood rotting and litter degrading basidiomycetes were screened for the production of lignocellulolytic enzymes such as, laccase, peroxidase, and cellulase using rapid micro quantification assay. Out of the 30 indigenous isolates Trametes gibbosa was identified to be a potential lignocellulolytic enzyme producer, producing a maximum amount of cellulase (299.66 $\pm 1.59 \mathrm{IU} / \mathrm{L})$ and laccase $(257.94 \pm 1.79 \mathrm{U} / \mathrm{L})$. Moreover, it is the second leading producer of peroxidase enzyme (170.19 $\pm 1.98 \mathrm{U} / \mathrm{L})$. Tricholomopsis sp. a wood rot basidiomycete was found to be the leading lignin decomposer with maximum peroxidase activity $(287.84 \pm 2 \mathrm{U} / \mathrm{L})$ and second maximum laccase activity $(250.19 \pm 1.83 \mathrm{U} / \mathrm{L})$. However, its cellulolytic potential was found to be moderate $(100.04 \pm 1.13 \mathrm{U} / \mathrm{L})$. A higher level of lignocellulolytic enzymes was recorded in wood rotting basidiomycetes, whereas very low levels of lignolytic enzymes were found in litter inhabiting basidiomycetes. However, their cellulolytic potential was found to be moderate.
\end{abstract}

\section{Introduction}

Lignocellulosic substrates have recently gained remarkable interest due to their wide biotechnological applications in the agricultural industry, food processing, paper, and fuel industries. The biotechnological process not only uses lignocellulosic wastes as an energy feedstock but is also associated with pollution abatement $[1,2]$. These substrates are mainly composed of cellulose, hemicellulose, and lignin [3]. Cellulose is a biopolymer and has been widely used in paper making, as a source of sugars, and as a precursor for bioethanol production and for various purposes. Recovery of cellulose from lignocellulosic substrates of physical and chemical methods is an energy intensive process as the lignin acts as barrier for them [4]. Naturally, the cellulose from these lignocellulosic substrates can be utilized by a wide variety of wood rotting and litter degrading fungi. They produce enzymes such as laccase and peroxidase for the degradation of lignin and cellulase for the cellulose utilization. In general, mushrooms become accustomed to the abundant supply of lignocellulosic substrates, digest them, utilize them for their growth, and thereby they recycle them. The efficiency of utilizing lignocellulosic waste materials depends on their ability to secrete potential hydrolytic, oxidative enzymes which differ from species to species [5]. Studies have shown that wood rot fungi invest part of their metabolic energy to produce lignocellulolytic enzymes for the purpose of degrading lignin $[6,7]$. The enzymes produced using agroindustrial or organic wastes from mushrooms have wide application in the field of diagnostic medicine, textile, paper, and biofuel industries, which accounts for $40 \%$ of global enzyme market supply [8-10].

The major objective of this study is to tap out the potential lignocellulolytic enzyme producer from various wood rot and litter fungi and to compare them. Screening is the major strategy to identify the efficient industrially viable enzyme producer from environmental sources. Efficient, rapid screening systems are needed to identify and quantify 
these classes of enzymes using specific substrate. Hence, in this study a rapid microquantification assay has been used for the determination of lignocellulolytic enzymes such as laccase, peroxidase, and cellulase from wood rot and litter degrading basidiomycetes collected indigenously from places in and around Chennai.

\section{Materials and Methods}

2.1. Chemicals. 2,2'-Azino-bis-3-ethylbenzothiazoline-6sulfonate (ABTS), 2-methoxyphenol, and carboxymethyl cellulose were from Sigma-Aldrich, and $\mathrm{H}_{2} \mathrm{O}_{2}$ (perhydrol, $30 \%$ ) was obtained from Boehringer. All other chemicals used were of analytical grade.

\subsection{Organisms and Fermentation for Enzyme Production.} The fruiting bodies of mushrooms found growing on the trees, decomposing logs, and soils at different places in and around Chennai, Tamil Nadu, India, were collected and isolated in pure cultures on PDA and revived before every assay. The collected mushrooms were further identified using field characters such as substrate for growth and occurrence of fruiting body [11], morphological characters such as pileus, lamellae, stipe, and fruiting bodies [12], and microscopic characters such as spore print, cystidia, and hyphal arrangement [13]. The isolated culture was deposited in the fungal culture collection, Centre for Advanced Studies in Botany. The fungal isolates were precultured in Potato dextrose agar (PDA) medium at $28^{\circ} \mathrm{C}$ for 14 days and agar plugs $(10 \mathrm{~mm}$ in diameter) were inoculated in the liquid medium. A basal liquid medium was prepared in the following composition: glucose $-10 \mathrm{~g} / \mathrm{L}$, yeast extract $-3 \mathrm{~g} / \mathrm{L}$, peptone $-1 \mathrm{~g} / \mathrm{L}, \mathrm{MgSO}_{4} \cdot 7 \mathrm{H}_{2} \mathrm{O}-1 \mathrm{~g} / \mathrm{L}$, and $\mathrm{KH}_{2} \mathrm{PO}_{4} \cdot 3 \mathrm{H}_{2} \mathrm{O}-$ $1 \mathrm{~g} / \mathrm{L}$. The mycelium from the plate was inoculated with $50 \mathrm{~mL}$ of liquid medium in a $250 \mathrm{~mL}$ Erlenmeyer flask. The cultures were incubated at $25^{\circ} \mathrm{C}$ for 30 days under static condition at optimum $\mathrm{pH}$ of $6.5 \pm 0.5$. The culture filtrate was then separated and centrifuged at $5000 \mathrm{rpm}$ for $15 \mathrm{~min}$. The supernatant was carefully transferred and was treated as the crude enzyme fluid and assays were performed by the microtitre plate method.

2.3. Microquantification of Lignocellulolytic Enzymes. The laccase activity was monitored by measuring the maximum absorption of oxidation of ABTS (2,2 ${ }^{\prime}$-azinobis-3ethylbenzthiazoline-6-sulfonate) substrate at $25^{\circ} \mathrm{C}$. The reaction mixture $(200 \mu \mathrm{L})$ containing $10 \mu \mathrm{L}$ of enzyme sample, $10 \mu \mathrm{L}$ of $10 \mathrm{mM} / \mathrm{L}$ ABTS, and $180 \mu \mathrm{L}$ of $50 \mathrm{mM} / \mathrm{L}$ sodium acetate buffer solution ( $\mathrm{pH}$ of 4.5) was incubated for $3 \mathrm{~min}$ and the laccase activity of crude enzyme was determined by measuring the absorbance at $420 \mathrm{~nm}$ using ELISA Reader model Multiskan EX. One unit of enzyme activity was defined as the amount of enzyme catalyzing the oxidation of $1 \mu \mathrm{mol}$ of substrate per minute [14].

Peroxidase activity was determined by monitoring the oxidation of guaiacol at room temperature, that is, $25 \pm 2^{\circ} \mathrm{C}$. The reaction mixture $(200 \mu \mathrm{L})$ contained $100 \mathrm{mM}$ of citrate phosphate buffer ( $\mathrm{pH} 4.0$ ), $1 \mathrm{mM}$ of $30 \%$ hydrogen peroxidase solution, $1 \mathrm{mM}$ of guaiacol, and the supernatant of culture filtrate. The absorbance was determined at $414 \mathrm{~nm}$ using ELISA reader model Multiskan EX. One unit of peroxidase activity was defined as the amount of the enzyme, which leads to the oxidation of $1 \mu \mathrm{mol}$ of substrate per minute [15]. Both the laccase and total peroxidase were performed in microtitre plates $[16,17]$.

Cellulase was initially done with tubes, then the final incubation and the absorbance were carried out in microtitre plates. Cellulase activity was assayed by mixing $50 \mu \mathrm{L}$ of proper enzyme dilution with $50 \mu \mathrm{L}$ of $2 \%$ carboxymethylcellulose solution in a $0.05 \mathrm{M}$ citrate buffer $(\mathrm{pH} 4.8)$ and incubating the mixture for $30 \mathrm{~min}$ at $50^{\circ} \mathrm{C}$ in a water bath with moderate shaking. Dinitrosalicylic acid was added and boiled for $5 \mathrm{~min}$. The absorbance was measured at $540 \mathrm{~nm}$ [18]. The sample and buffer were poured into the well using multichannel pipettes. All the samples were measured with microtitre plate reader model Multiskan EX [19]. One unit of CMC activity is defined as the amount of enzyme needed to liberate $1 \mathrm{~mol}$ of glucose/min. Glucose was used as standard for CMC activity.

2.4. Statistical Analysis. Values are expressed as means \pm S.D. and analyzed using one-way ANOVA for comparisons of means. The statistical analysis was performed using SPSS version 10 for Windows (SPSS, Inc.).

\section{Results}

A total of 30 indigenous collected species of basidiomycetes were identified and substrates from which it is isolated were mentioned in Table 1 . The collected basidiomycetes were evaluated for their extracellular lignocellulolytic enzyme production using a microtitre plate method after submerged fermentation. Out of these enzymes, laccase plays a dynamic role as the best lignin upgrade in lignin degrading fungi. The results of the screening of laccase were shown in Figure 1; it shows that Trametes gibbosa $(257.94 \pm 1.79 \mathrm{U} / \mathrm{L})$ was the highest producer of this enzyme, which was followed by Tricholomopsis sp. $(250.19 \pm 1.83 \mathrm{U} / \mathrm{L})$ and Trametes hirsuta $(185.95 \pm 2.33 \mathrm{U} / \mathrm{L})$, whereas a low enzyme activity was observed in Agrocybe sp. (13.23 $\pm 1.45 \mathrm{U} / \mathrm{L})$ (Figure 2).

Peroxidases are one of the key enzymes responsible for the degradation of lignocellulose, of which peroxidases are considered to be the most effective in the removal of lignin and were quantified in this study using rapid microtitre plate based quantitative peroxidase assay (Figure 3). In this study, Tricholomopsis sp. showed the highest peroxidase activity of $287.84 \pm 2 \mathrm{U} / \mathrm{L}$ followed by Trametes gibbosa (170.19 \pm $1.98 \mathrm{U} / \mathrm{L}$ ) and Lentinus edodes (117.96 $\pm 2.88 \mathrm{U} / \mathrm{L}$ ) (Figure 2). Very least peroxidase activity was recorded in Lepiota sp. $(4.7 \pm 1.11 \mathrm{U} / \mathrm{L})$ (Figure 2$)$.

Cellulase refers to hydrolytic enzymes that catalyse the cellulolysis. Cellulase have wide range of potential applications in various industries. Figure 3 revealed that, out of 30 fungi, six indigenous fungi were identified with a potential cellulolytic capacity. Trametes gibbosa, member of the polyporus fungi, exhibited the highest cellulolytic activity 
TABLE 1: Fungal cultures isolated and their substrates.

\begin{tabular}{|c|c|c|c|}
\hline $\begin{array}{l}\text { Serial } \\
\text { number }\end{array}$ & $\begin{array}{c}\text { Name of organism } \\
\text { isolated }\end{array}$ & $\begin{array}{l}\text { Name of } \\
\text { substrate }\end{array}$ & Group \\
\hline 1 & Agaricus bisporus & Soil & \multirow{11}{*}{$\begin{array}{l}\text { Litter degrading } \\
\text { basidiomycetes }\end{array}$} \\
\hline 2 & Agaricus heterocystis & Soil & \\
\hline 3 & Agaricus sp. & Soil & \\
\hline 4 & Agrocybe sp. & Soil & \\
\hline 5 & Cantharellus sp. & Soil & \\
\hline 6 & Chlorophyllum sp. & Soil & \\
\hline 7 & Coprinus sp. & Soil & \\
\hline 8 & Lepiota sp. & Soil & \\
\hline 9 & Leucocoprinus sp. & Soil & \\
\hline 10 & Macrolepiota sp. & Soil & \\
\hline 11 & Omphalina sp. & Soil & \\
\hline 12 & Auricularia sp. & Wood & \multirow{19}{*}{$\begin{array}{l}\text { Wood rot } \\
\text { basidiomycetes }\end{array}$} \\
\hline 13 & Calocybe sp. & Wood & \\
\hline 14 & Ganoderma lucidum & Wood & \\
\hline 15 & Ganoderma sp. & Wood & \\
\hline 16 & Hypsizygus ulmarius & Wood & \\
\hline 17 & Lentinus edodes & Wood & \\
\hline 18 & Lentinus tuber-regium & Wood & \\
\hline 19 & Phellinus sp. & Wood & \\
\hline 20 & Pleurotus eryngii & Wood & \\
\hline 21 & Pleurotus florida & Wood & \\
\hline 22 & $\begin{array}{c}\text { Pleurotus djamor var. } \\
\text { roseus }\end{array}$ & Wood & \\
\hline 23 & Pleurotus sp.1 & Wood & \\
\hline 24 & Pleurotus sp.2 & Wood & \\
\hline 25 & Pluteus sp. & Wood & \\
\hline 26 & Psathyrella candolleana & Wood & \\
\hline 27 & Schizophyllum commune & Wood & \\
\hline 28 & Trametes gibbosa & Wood & \\
\hline 29 & Trametes hirsuta & Wood & \\
\hline 30 & Tricholomopsis sp. & Wood & \\
\hline
\end{tabular}

of $299.143 \pm 1.59 \mathrm{IU} / \mathrm{L}$ (Figure 3 ). The other wood rots Lentinus edodes and Tricholomopsis sp. Were recorded to possess the highest enzyme activity $(294.143 \pm 2.08 \mathrm{IU} / \mathrm{L}$ and $101.044 \pm 1.13 \mathrm{IU} / \mathrm{L}$, resp.). However, Hypsizygus ulmarius, Pleurotus florida, and Tramates hirsuta were also shown to possess considerable cellulolytic activity of $98.42 \pm 1.45 \mathrm{IU} / \mathrm{L}$, $93.78 \pm 2.6 \mathrm{IU} / \mathrm{L}$, and $79.23 \pm 2.55 \mathrm{IU} / \mathrm{L}$, respectively.

\section{Discussion}

A number of research works were carried out to evaluate the enzymatic potential by classical methods and these methods are time consuming and require more amount of substrate for quantification. Hence, to quantify the lignocellulolytic enzymes in short duration, microquantification technique is the best method of choice. Most wood inhabiting fungi showed good laccase activity except a few species such as

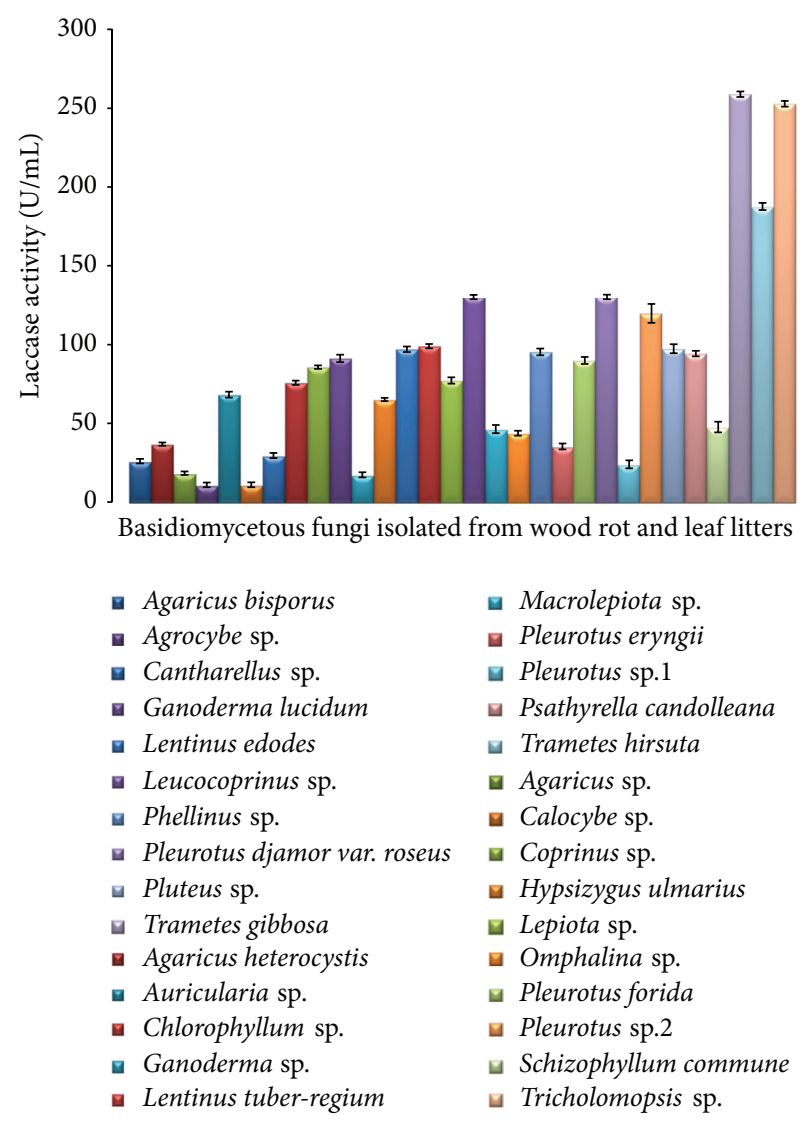

FIGURE 1: Quantification of Laccase activity determined using ABTS by microtitre plate assay. Extracellular enzymes of laccase production from cultures of basidiomycetes. All values are medium of three replications \pm standard error.

Ganoderma sp., Calocybe sp., and one wild Pleurotus sp. where very low level of enzyme activity was recorded. Conversely, the litter inhabiting fungi such as Agrocybe sp. and Agaricus sp. showed very low level of enzyme activity. This is due to the difference in substrate in which they grow; that is, the wood rot fungi produce more laccase enzyme than the litter degrading fungi [20]. The laccase enzyme finds its major application in processes such as delignification, biopulping, biosorption, and wine clarification, and Trametes was the first reported laccase producer. Out of the different cultures screened Trametes gibbosa and Trametes hirsuta have been proven to be potential candidates with the highest laccase activity, in addition to Tricholomopsis sp. Thus, the results of our study correlate with studies made by Songulashvili et al. [21] where the study showed that the genus Trametes expressed comparatively a higher laccase activity than the other species of wood rot basidiomycetes. Moreover, most common laccase producers are wood rot fungi; especially, polyporales play a major role in efficient degradation of lignin $[20,22]$. Similarly, in this study most of white rots including Lentinus edodes, Pleurotus djamor var. roseus, and Pleurotus sp. 2 cultures exhibited a comparatively better laccase activity. Screening methods play a major role in the identification of potential candidate for biotechnological applications. 


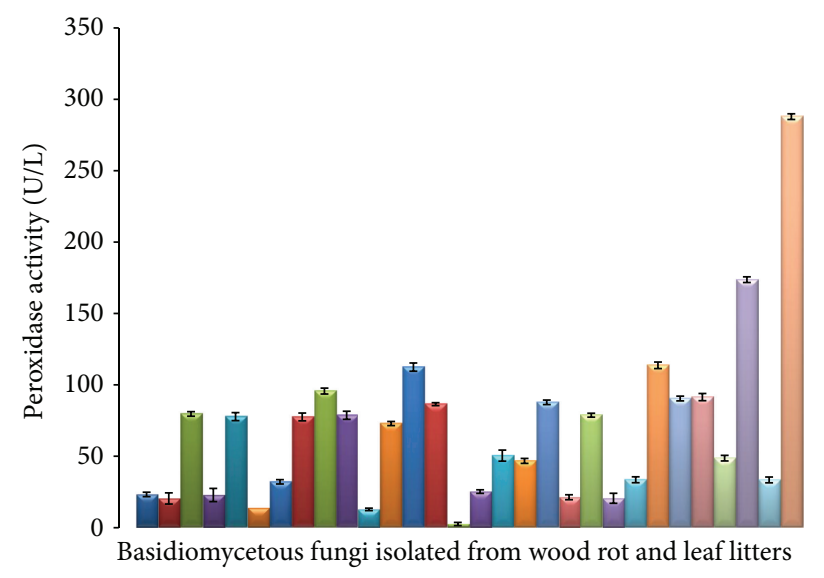

- Agaricus bisporus

- Agrocybe sp.

- Cantharellus sp.

- Ganoderma lucidum

- Lentinus edodes

- Leucocoprinus sp.

口 Phellinus sp.

$\square$ Pleurotus djamor var. roseus

- Pluteus sp.

- Trametes gibbosa

- Agaricus heterocystis

- Auricularia sp.

- Chlorophyllum sp.

- Ganoderma sp.

- Lentinus tuber-regium
- Macrolepiota sp.

- Pleurotus eryngii

- Pleurotus sp.1

- Psathyrella candolleana

- Trametes hirsuta

- Agaricus sp.

- Calocybe sp.

- Coprinus sp.

- Hypsizygus ulmarius

¿ Lepiota sp.

- Omphalina sp.

- Pleurotus forida

- Pleurotus sp.2

$\checkmark$ Schizophyllum commune

- Tricholomopsis sp.

FIgURE 2: Quantification of peroxidase activity using guaiacol by microtitre plate assay. Extracellular enzymes of peroxidase production from cultures of basidiomycetes. All values are medium of three replications \pm standard error.

The rapid microtitre plate screening method used in this study showed promising results similar to those of Okino et al. [23] where they developed a quick screening method and isolated 116 Brazilian tropical rainforest basidiomycetes expressing laccase enzyme. Substrate for the enzyme is another factor for accurate quantification of the enzymes. In case of enzyme laccase, ABTS was found to be the suitable substrate, as it rapidly detects this enzyme more accurately in this method.

For identification of a high level peroxidase producers, the time and reliability are the considerable factors for determining the activity. Rapid microquantification assay was proved to be the reliable and short time method for determination of peroxidase enzymes. In this study, the peroxidase enzymes were determined by rapid microquantification assay. Wood rot fungi showed higher production of extracellular peroxidase than the litter degrading basidiomycetes. This may due to the fact that wood rots require peroxidase enzyme and possess high oxidative ability to degrade lignin [24]. The rapid microtitre plate based quantitative peroxidase assay used in this study showed promising results, comparable to those of classical quantitative spectrophotometric assay based screening studies carried out by Dhouib et al.

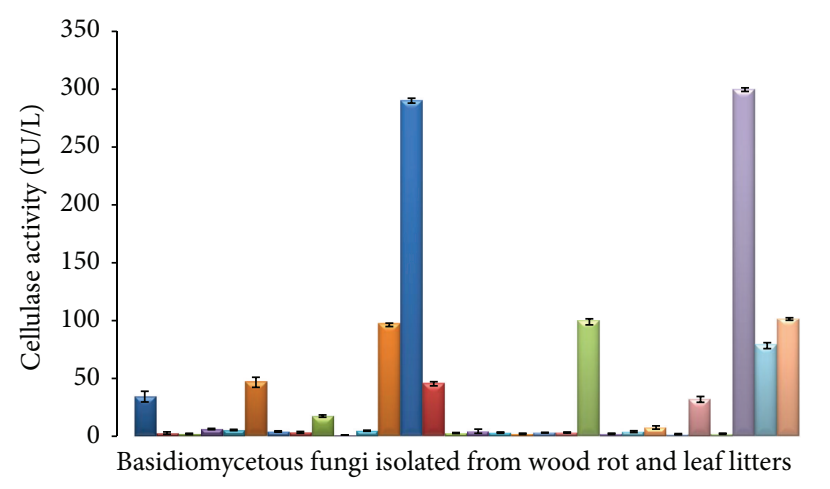

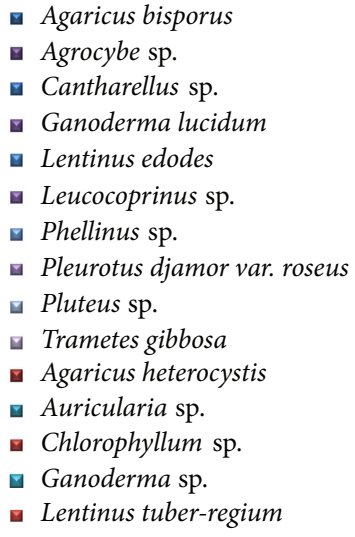

- Macrolepiota sp.

- Pleurotus eryngii

$\square$ Pleurotus sp.1

๑ Psathyrella candolleana

$\checkmark$ Trametes hirsuta

- Agaricus sp.

- Calocybe sp.

- Coprinus sp.

- Hypsizygus ulmarius

$\square$ Lepiota sp.

Omphalina sp.

$\square$ Pleurotus forida

$\square$ Pleurotus sp.2

$\checkmark$ Schizophyllum commune

$\square$ Tricholomopsis sp.
FIGURE 3: Quantification of cellulase activity using carboxymethyl cellulose by microtitre plate assay. Extracellular enzymes of cellulase production from cultures of basidiomycetes. All values are medium of three replications \pm standard error.

[25]; Taboada-Puig et al. [26]; Järvinen et al. [27]. Sometimes, the fungal strains from white rot group are able to produce laccase more than the peroxidase. Hence, it is essential to quantify the target catalyst from large number of strains which is extremely important. Accuracy for oxidative enzyme screening depends on the chromogenic substances used for its detection. In this study, the guaiacol was used as the chromogenic substrate for the detection of peroxidase. Similar studies by Mercer et al. [28] screened the peroxidase activity of actinomycetes using rapid microquantitative assay and demonstrated that this technique was effective in rapid screening. Out of the 30 fungal strains screened, almost all wood rot fungi exhibited significant peroxidase activity except for a few species such as Pleurotus eryngii and Lepiota sp.

Nowadays, significant attention has been devoted to the knowledge of cellulase production and the challenges in cellulase research especially in improving the process economics of various industries [29]. Cellulase had a series of applications in food, pulp, fuel, textile, and so forth. Hence, the screening of cellulolytic potetial fungi for its ability towards industry level is essential nowadays. The microquantification cellulase assay using carboxymethyl cellulose (CMC) showed promising results in this study and was comparable with that of classical screening assay in many wood rots and litter fungi tested by Dhouib et al. [25] where they screened 224 
fungal strains from Zimbabwe for cellulolytic activities. The microquantification cellulase assay using CMC was the best method; evidence from previous studies was made by king et al. [30] where the study compared the cellulase production of different fungi such as Trichoderma reesei, Fusarium oxysporum, and S. sclerotina, using microtitre plate methods. The results showed that $T$. reese $i$ showed maximum cellulase production in CMC and arabinoxylan substrates. Wang et al. [31] reported that three strains of Agrocybe aegerita utilized non-lignin-cellulose more efficiently than the other strains in the study and their cellulose-degrading activity was slightly lower. Similar results were observed in our study that Agrocybe sp. exhibited lower cellulase activity. White rot fungi produced more laccase and peroxidase extracellularly than cellulase at low rate during anamorphic phase of the basidiomycetes. In contrast, the Trametes produces cellulase at high levels than the litter degrading fungi, which may due to the factors such as diversity of the environment, adaption, evolution, and modification of genes by the organisms [32, 33].

The rapid quantification assay technique used in this screening study identified the efficient lignocellulolytic enzymes producing indigenous isolates such as Trametes gibbosa, Tricholomopsis sp., Trametes hirsuta, Lentinus edodes, and Pleurotus species from native environments of Tamil Nadu, India. Nevertheless, most of the white rots and litter degrading fungi produce laccase, peroxidase and cellulase enzymes, their level differs depends on the substrate that is wood or soil or litter, from which it is isolated. Some of the same genus have different level of enzyme production which is totally based on the species variation and also the genetic modification of the strains. Thus, the study emphasis to explore the basidiomycetes fungi and its oxidative and hydrolytic enzymes was to evaluate the accurate efficacy of the fungi.

\section{Conclusion}

Thirty south Indian taxa of basidiomycetes were collected and screened for extracellular oxidative and hydrolytic enzymes using microtitre plate technique. The most promising results obtained with these ligninolytic fungal strains led to discovering the hidden potentials of some of the members of basidiomycetes. This study strives to unravel the immense lignin-degrading potential of basidiomycetes from South India and also to make this data available to promote future research.

\section{Conflict of Interests}

The authors declare that there is no conflict of interests regarding the publication of this paper.

\section{Acknowledgment}

The authors thank the Director of CAS in Botany for providing the necessary facility to carry out the research work.

\section{References}

[1] M. I. Massadeh, A. Fraij, and K. Fandi, "Effect of carbon sources on the extracellular lignocellulolytic enzymatic system of Pleurotus Sajor-Caju," Jordan Journal of Biological Sciences, vol. 3, no. 2, pp. 51-554, 2010.

[2] B. E. Lechner and V. L. Papinutti, "Production of lignocellulosic enzymes during growth and fruiting of the edible fungus Lentinus tigrinus on wheat straw," Process Biochemistry, vol. 41, no. 3, pp. 594-598, 2006.

[3] M. Dashtban, M. Maki, K. T. Leung, C. Mao, and W. Qin, "Cellulase activities in biomass conversion: measurement methods and comparison," Critical Reviews in Biotechnology, vol. 30, no. 4, pp. 302-309, 2010.

[4] D. Wesenberg, I. Kyriakides, and S. N. Agathos, "White-rot fungi and their enzymes for the treatment of industrial dye effluents," Biotechnology Advances, vol. 22, no. 1-2, pp. 161-187, 2003.

[5] P. Giardina, V. Faraco, C. Pezzella, A. Piscitelli, S. Vanhulle, and G. Sannia, "Laccases: a never-ending story," Cellular and Molecular Life Sciences, vol. 67, no. 3, pp. 369-385, 2010.

[6] A. Rescigno, P. Zucca, A. Flurkey, J. Inlow, and W. H. Flurkey, "Identification and discrimination between some contaminant enzyme activities in commercial preparations of mushroom tyrosinase," Enzyme and Microbial Technology, vol. 41, no. 5, pp. 620-627, 2007.

[7] E. Rodríguez, M. A. Pickard, and R. Vazquez-Duhalt, "Industrial dye decolorization by laccases from ligninolytic fungi," Current Microbiology, vol. 38, no. 1, pp. 27-32, 1999.

[8] Y. H. Tan and M. N. Wahab, "Extracellular enzyme production during anamorphic growth in the edible mushroom, Pleurotus sajor-caju," World Journal of Microbiology and Biotechnology, vol. 13, no. 6, pp. 613-617, 1997.

[9] D. Moldes, M. Lorenzo, and M. A. Sanromán, "Different proportions of laccase isoenzymes produced by submerged cultures of Trametes versicolor grown on lignocellulosic wastes," Biotechnology Letters, vol. 26, no. 4, pp. 327-330, 2004.

[10] G. V. Reddy, P. Ravindra Babu, P. Komaraiah, K. R. R. M. Roy, and I. L. Kothari, "Utilization of banana waste for the production of lignolytic and cellulolytic enzymes by solid substrate fermentation using two Pleurotus species (P. ostreatus and P. sajor-caju)," Process Biochemistry, vol. 38, no. 10, pp. 14571462, 2003.

[11] D. L. Largent and H. D. Thiers, How To Identify Mushrooms To Genus II: Field Identification of Genera, Mad River Press, 1977.

[12] D. L. Largent and D. E. Stuntz, How To Identify Mushrooms To Genus I: Macroscopic Features, Mad River Press, 1977.

[13] D. L. Largent, D. Johnson, D. E. Stuntz, and R. Watling, How To Identify Mushrooms To Genus III: Microscopic Features, Mad River Press, 1977.

[14] L. Liu, Z. Lin, T. Zheng et al., "Fermentation optimization and characterization of the laccase from Pleurotus ostreatus strain 10969," Enzyme and Microbial Technology, vol. 44, no. 6-7, pp. 426-433, 2009.

[15] M. Mansur, T. Suárez, J. B. Fernández-Larrea, M. A. Brizuela, and A. E. González, "Identification of a laccase gene family in the new lignin-degrading basidiomycete CECT 20197," Applied and Environmental Microbiology, vol. 63, no. 7, pp. 2637-2646, 1997.

[16] F. H. Arnold and G. Georgiou, Directed Enzyme Evolution: Screening and Selection Methods, Humana Press, 2003. 
[17] M. Heinzkill, L. Bech, T. Halkier, P. Schneider, and T. Anke, "Characterization of laccases and peroxidases from woodrotting fungi (family Coprinaceae)," Applied and Environmental Microbiology, vol. 64, no. 5, pp. 1601-1606, 1998.

[18] M. Mandels, R. Andreotti, and C. Roche, "Measurement of saccharifying cellulase," Biotechnology and bioengineering symposium, no. 6, pp. 21-33, 1976.

[19] Z. Xiao, R. Storms, and A. Tsang, "Microplate-based filter paper assay to measure total cellulase activity," Biotechnology and Bioengineering, vol. 88, no. 7, pp. 832-837, 2004.

[20] L. Levin, L. Papinutti, and F. Forchiassin, "Evaluation of Argentinean white rot fungi for their ability to produce ligninmodifying enzymes and decolorize industrial dyes," Bioresource Technology, vol. 94, no. 2, pp. 169-176, 2004.

[21] G. Songulashvilia, V. Elisashvilib, and S. P. Wassera, "Basidiomycetes laccase and manganese peroxidase activity in submerged fermentation of food industry wastes," Enzyme and Microbial Technology, vol. 41, no. 1-2, pp. 57-61, 2007.

[22] M. C. Saparrat, M. J. Martinez, M. N. Cabello, and A. M. Arambarri, "Screening for ligninolytic enzymes in autochthonous fungal strains from Argentina isolated from different substrata," Revista Iberoamericana de Micologia, vol. 19, no. 3, pp. 181-185, 2002.

[23] L. K. Okino, K. M. G. Machado, C. Fabris, and V. L. R. Bononi, "Ligninolytic activity of tropical rainforest basidiomycetes," World Journal of Microbiology and Biotechnology, vol. 16, no. 8-9, pp. 889-893, 2000.

[24] C. López, A.-G. Valade, B. Combourieu, I. Mielgo, B. Bouchon, and J. M. Lema, "Mechanism of enzymatic degradation of the azo dye Orange II determined by ex situ ${ }^{1} \mathrm{H}$ nuclear magnetic resonance and electrospray ionization-ion trap mass spectrometry," Analytical Biochemistry, vol. 335, no. 1, pp. 135149, 2004.

[25] A. Dhouib, M. Hamza, H. Zouari et al., "Autochthonous fungal strains with high ligninolytic activities from Tunisian biotopes," African Journal of Biotechnology, vol. 4, no. 5, pp. 431-436, 2005.

[26] R. Taboada-Puig, T. Lú-Chau, M. T. Moreira, G. Feijoo, M. J. Martínez, and J. M. Lema, "A new strain of Bjerkandera sp. production, purification and characterization of versatile peroxidase," World Journal of Microbiology and Biotechnology, vol. 27, no. 7, p. 1735, 2011.

[27] J. Järvinen, S. Taskila, R. Isomäki, and H. Ojamo, "Screening of white-rot fungi manganese peroxidases: a comparison between the specific activities of the enzyme from different native producers," AMB Express, vol. 2, no. 62, 2012.

[28] D. K. Mercer, M. Iqbal, P. G. G. Miller, and A. J. McCarthy, "Screening actinomycetes for extracellular peroxidase activity," Applied and Environmental Microbiology, vol. 62, no. 6, pp. 2186-2190, 1996.

[29] R. C. Kuhad, G. Rishi, and S. Ajay, "Microbial cellulases and their industrial applications," Enzyme Research, vol. 2011, 10 pages, 2011.

[30] B. C. King, M. K. Donnelly, G. C. Bergstrom, L. P. Walker, and D. M. Gibson, "An optimized microplate assay system for quantitative evaluation of plant cell wall-degrading enzyme activity of fungal culture extracts," Biotechnology and Bioengineering, vol. 102, no. 4, pp. 1033-1044, 2009.

[31] N. Wang, F. Shen, Q. Tan, M. J. Chenand, and Y. J. Pan, "Detection and analysis of extracellular Enzyme activities in Agrocybe aegerita strains," Mushroom Biology and Mushroom Products, pp. 197-204, 2002.
[32] H.-B. Yu, L. Li, X.-Y. Zhang, and H.-Y. Huang, "Effects of wood species and enzyme production on lignocellulose degradation during the bioderadation of three native woods by Trametes versicolor," Forest Products Journal, vol. 58, no. 4, pp. 62-65, 2008.

[33] P. Baldrian and V. Valášková, "Degradation of cellulose by basidiomycetous fungi," FEMS Microbiology Reviews, vol. 32, no. 3, pp. 501-521, 2008. 

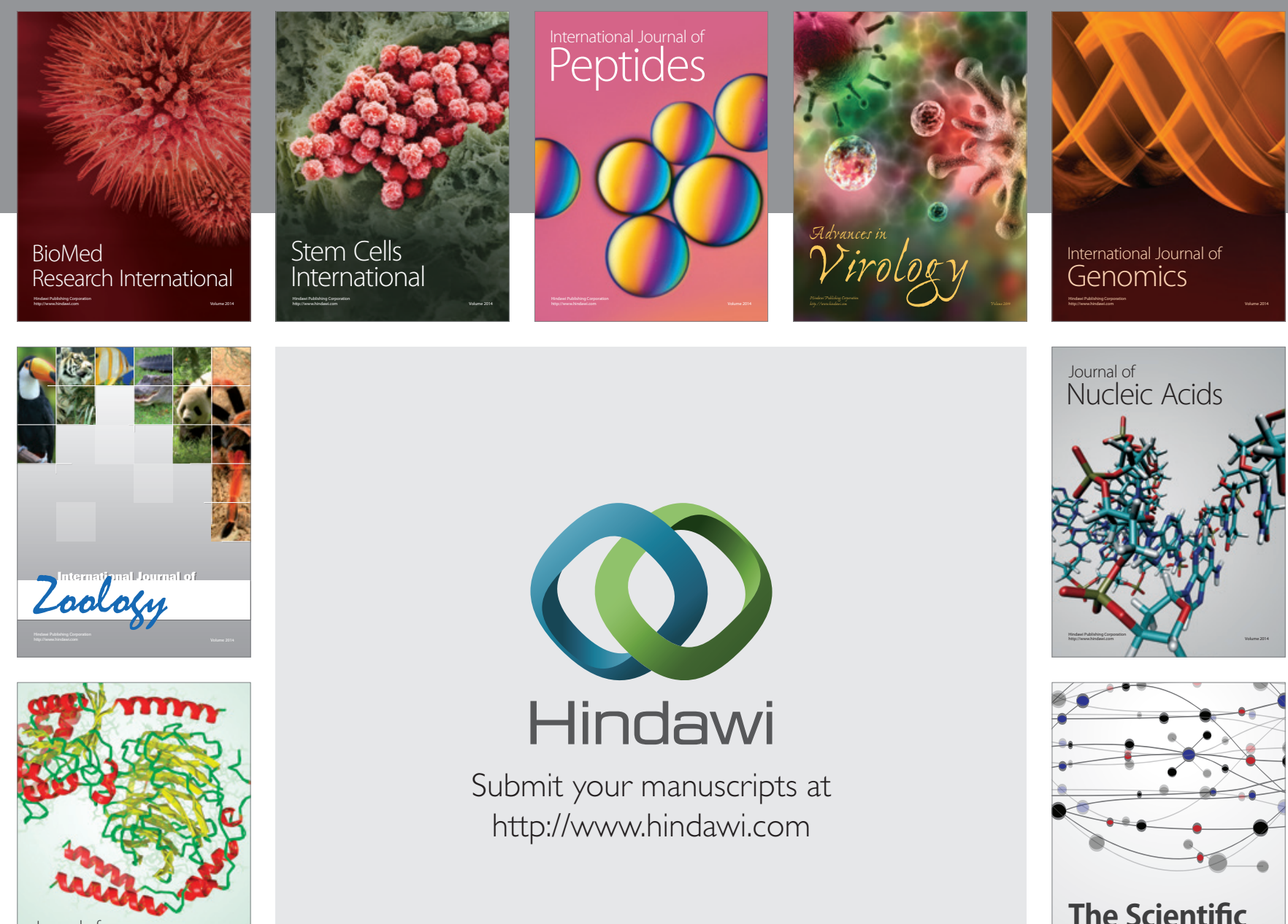

Submit your manuscripts at

http://www.hindawi.com

Journal of
Signal Transduction
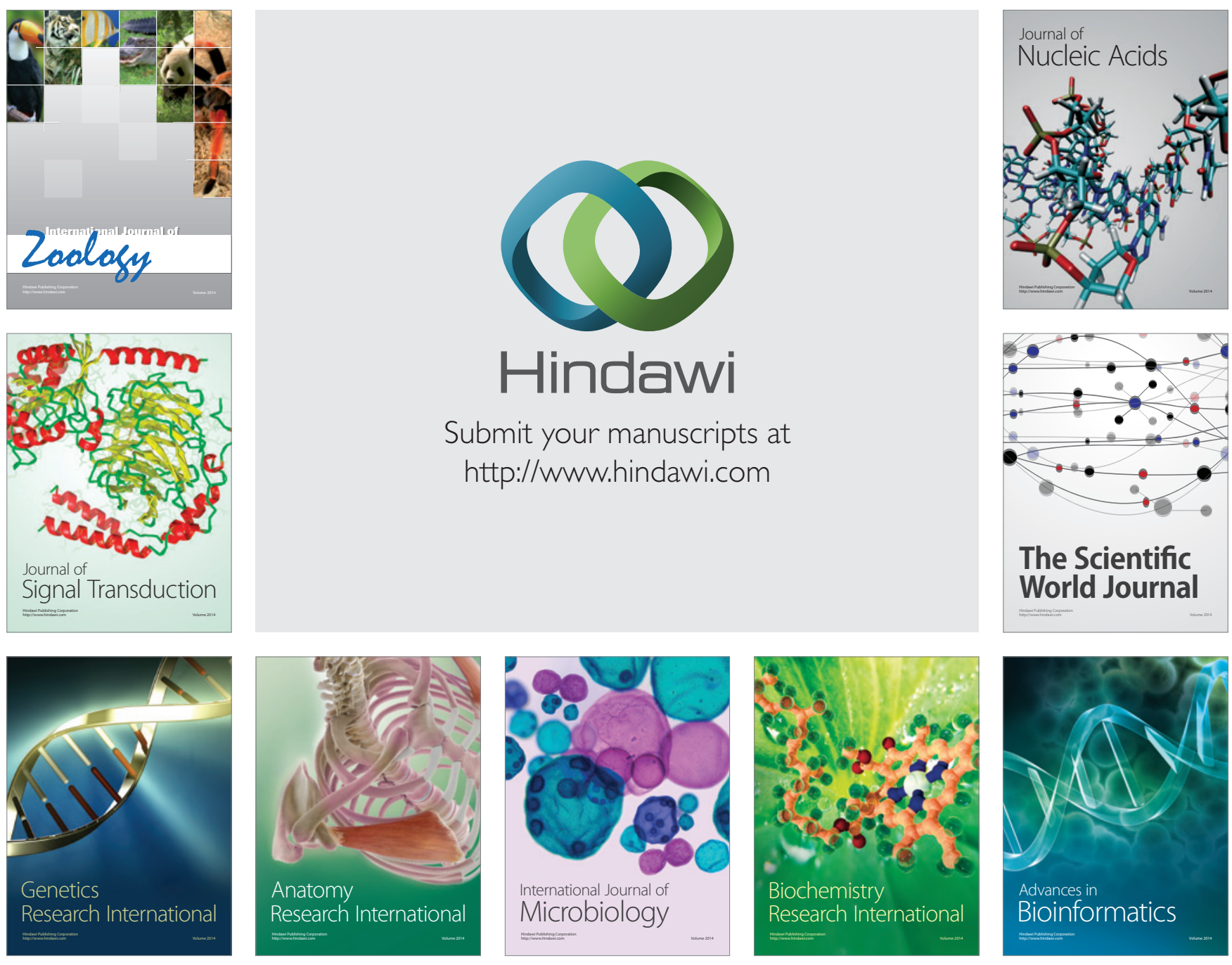

The Scientific World Journal
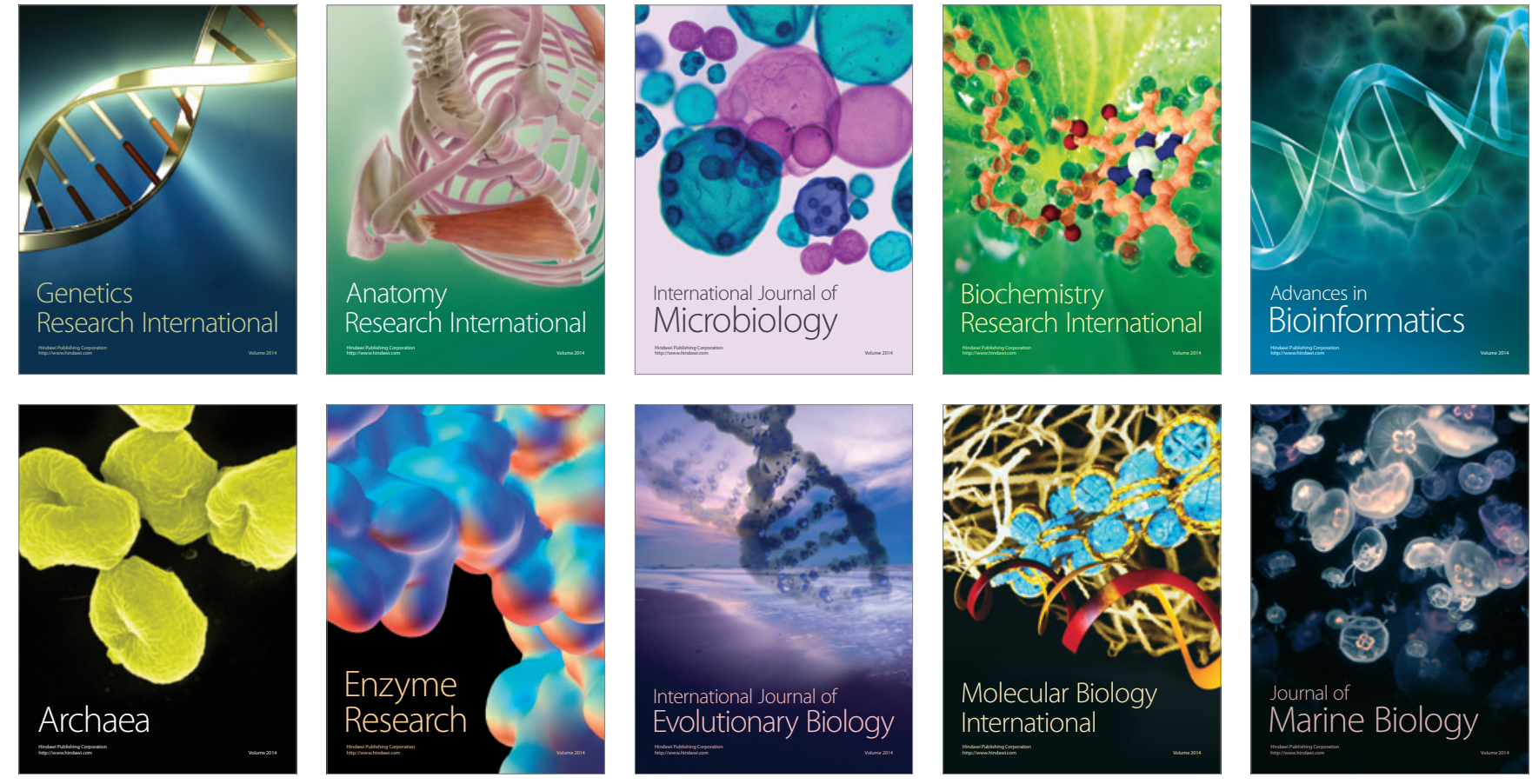